\title{
Harmonics reduction of three phase five-level Neutral-Point-Clamped Multilevel Inverter
}

\begin{abstract}
This paper presents the development of a 5-level Neutral-Point-Clamped Multilevel Inverter (NPCMI) simulation model. Based on the desired output voltage profile and switching states of the multilevel inverter, the triggering signals are calculated and determined. The best values of these signals are then chosen for the triggering angle and duration for each switch where a low Total Harmonics Distortion (THD) of output voltage is obtained.
\end{abstract}

Keyword: Neutral-point-clamped; Multilevel inverter; Triggering angle 